\title{
ANALISIS ZONA BAHAYA GEMPABUMI BERDASARKAN METODE DETERMINISTIK DAN PENDEKATAN GEOMORFOLOGI KOTA PADANG SUMATERA BARAT
}

\author{
Azis Riyanti ${ }^{1}$, Syamsurijal Rasimeng ${ }^{2}$ \\ 1,2Jurusan Teknik Geofisika, Fakultas Teknik Universitas Lampung \\ Jl. Prof. Soemantri Brodjonegoro No. 01, Bandar Lampung 35145 \\ Corresponding author: azisriyanti@gmail.com \\ Manuscript received: June 3, 2019; revised: July 11, 2019; \\ Approved: July 18, 2019; available online: July 26, 2019
}

\begin{abstract}
Abstrak - Telah dilakukan penelitian tentang analisis bahaya gempabumi berdasarkan metode deterministik dan pendekatan geomorfologi Kota Padang dengan tujuan untuk mengetahui nilai percepatan tanah maksimum (PGA) dan amplifikasi dari sumber gempa patahan Suliti dan Sumber gempa Subduksi serta menentukan kelas tanah berdasarkan gelombang geser (Vs30). Untuk mendapatkan nilai PGA, terdapat beberapa persamaan atenuasi yang digunakan untuk mencari besarnya guncangan yang dihasilkan apabila terjadi gempa dangkal. Untuk sumber gempa patahan, persamaan atenuasi yang digunakan adalah persamaaan Boore-Atkinson, Campbell-Bozorgnia, dan Chiou-Young. Sedangkan persamaan atenuasi yang digunakan untuk mendapatkan nilai PGA dari sumber gempa subduksi adalah Atkinson-Boore, Youngs, serta Zhao. Nilai PGA sumber gempa Subduksi di batuan dasar 0,0374 g. Sementara nilai PGA di permukaan sebesar 0,0769 g. Sedangkan untuk nilai PGA pada sumber gempa patahan (Patahan Suliti) di batuan dasar berkisar antara 0,0376 g, sementara nilai PGA di permukaan berkisar 0,0573 g. Daerah yang memiliki dampak parah jika terjadi gempa yang bersumber dari patahan adalah Kecamatan Koto Tengah, Kcamatan Padang Barat, dan Kecamatan Padang Utara dengan nilai amplifikasi tertinggi yakni 1,7690 (> 9 kali) yang menunjukkan bahwa perbesaran gelombang didaerah tersebut tinggi. Sedangkan jika terjadi gempa dengan sumber gempa subduksi daerah yang sangan rawan adalah Kecamatan Padang Barat, Kecamatan Koto Tengah, Kecamatan Padang Utara dengan nilai amplifikasi 2,0607 (>9 kali).
\end{abstract}

\begin{abstract}
Research on earthquake hazard analysis based on deterministic methods and the geomorphology approach of Padang City has been carried out to determine the maximum soil acceleration (PGA) and amplification of the source of the Suliti faults and Earthquake Subduction and determine soil classes based on shear waves (Vs30). The PGA value, several attenuation equations are used to find the magnitude of the shock produced when a shallow earthquake occurs. For the source of fault earthquakes, the attenuation equations used are the equivalent of Boore-Atkinson, Campbell-Bozorgnia, and Chiou-Young. While the attenuation equations used to obtain PGA values from subduction earthquake sources are Atkinson-Boore, Youngs, and Zhao. PGA value of earthquake source Subduction in bedrock $0.0374 \mathrm{~g}$. While the PGA value on the surface is $0.0769 \mathrm{~g}$. Whereas the PGA value in the fault source (Hard Fault) in bedrock ranged from $0.0376 \mathrm{~g}$, while the PGA value on the surface ranged from $0.0573 \mathrm{~g}$. Areas that have a severe impact if an earthquake originates from a fault are Koto Tengah District, West Padang Subdistrict, and North Padang Subdistrict with the highest amplification value of 1.7690 (> 9 times) which indicates that the magnification of the area is high. Whereas in the case of an earthquake with an earthquake source subduction area which is very vulnerable is West Padang District, Koto Tengah District, Padang Utara District with an amplification value of 2.0607 ( $>9$ times).
\end{abstract}

Keywords: DSHA, Vs30, PGA, Amplification

How to cite this article:

Rianti, A. dan Rasimeng, S.. 2019. Analisis Zona Bahaya Gempabumi Berdasarkan Metode Deterministik dan Pendekatan Geomorfologi Kota Padang Sumatera Barat. Jurnal Geofisika Eksplorasi, 5 (2) p.101-

115. doi: 10.23960/jge.v5i2.26 


\section{PENDAHULUAN}

Indonesia adalah negara rawan gempabumi. Hal ini disebabkan oleh adanya pertemuan 3 lempeng aktif, yaitu dari Lempeng Eurasia yang bergerak relatif ke arah tenggara dengan kecepatan kurang lebih 0,4 cm/tahun, Lempeng Indo - Australia yang bergerak relatif ke arah utara dengan kecepatan kurang lebih 7 cm/tahun dan Lempeng Pasifik yang bergerak relatif kearah barat dengan kecepatan kurang lebih $11 \mathrm{~cm} /$ tahun. Akibat bertemunya ketiga lempeng aktif tersebut, maka Indonesia merupakan negara yang sering terjadi gempabumi (Athanasius dan Solikhin, 2015).

Gempabumi ini umumnya bersifat merusak disebabkan terjadi pada kedalaman dangkal serta magnitudonya cukup besar dan terletak dekat permukiman dan aktivitas penduduk. Dengan adanya studi bahaya guncangan tanah maka ada suatu dasar untuk membuat kebijakan tata ruang wilayah yang berbasis mitigasi bahaya gempabumi.

Salah satu faktor yang menentukan besarnya potensi bahaya seismik adalah sifat fisik batuan. Pengukuran sifat fisik tanah dalam daerah luas memerlukan waktu dan biaya yang besar oleh sebab itu untuk keperluan pemetaan skala regional perlu dikembangkan metode yang cepat, murah dan berdaya-guna. Salah satu metoda pendugaan kecepatan gelombang permukaan $\mathrm{V}_{\text {s30 }}$ sebagai dasar klasifikasi batuan, telah dikembangkan di Jepang dengan menggunakan klasifikasi geomorfologi sebagai parameter.

Tujuan dalam penelitian ini adalah sebagai berikut:

1. Mengetahui nilai $\mathrm{V}_{\mathrm{s} 30}$ dari pendekatan geomorfologi.

2. Mengrtahui nilai PGA dan amplifikasi dari sumber gempa patahan Suliti dan sumber gempa subduksi (Mid 2 Sumatera).

3. Menentukan kelas tanah berdasarkan gelombang geser $\left(\mathrm{V}_{\mathrm{s} 30}\right)$ terhadap Kota Padang.

\section{TINJAUAN PUSTAKA}

\subsection{Geologi Regional Kota Padang}

Tatanan fisiografi daerah Padang dan sekitarnya merupakan daerah paparan delta yang berhadapan dengan endapan laut terbuka yang dibatasi oleh graben berupa patahan-patahan di bagian timur dan barat yang berarah hampir barat laut hingga tenggara. Zona ini dicirikan seri endapan kuarter yang terdiri dari endapan pantai, endapan swamp, endapan alluvial. Dataran tersebut terpisah oleh laut terbuka dan pematang pantai yang bagian belakangnya terbentuk rawa-rawa pantai sebagai endapan swamp. Pada masa Mesozoikum terjadi lagi sedimentasi di laut dangkal dan disusun oleh pengangkatan, penerobosan, pemalihan dan penyesaran dizaman kapur dan dengan disertai terangkatnya batuan affiolit. Tektonik zaman tersier diawali dengan kegiatan magmait, kemudian pengendapan di daratan sampai laut dangkal dan pada zaman kuarter dikuasai oleh kegiatan gunungapi.

Formasi daerah penelitian terdiri dari Formasi Barisan, Formasi Lemau. Formasi Barisan terdiri dari: filit, sabak, batugamping, greywacke berumur perm. Litologi Formasi Lemau terdiri atas breksi dengan sisipan batupasir dan lempung, pada beberapa tempat menyerpih dan mengandung lapisan batubara. Sisipan batupasir berwarna abu-abu sampai kekuningan dengan ukuran butir halus, klastik dan berkomposisi dasitan, mengandung glaukonit, memperlihatkan perlapisan dan mempunyai struktur sedimen paralel laminasi. Dari adanya kandungan glaukonit formasi ini diperkirakan diendapkan dalam lingkungan laut dangkal. Batuan penyusun daerah penelitian ini terdiri dari kipas alluvium, andesit dan tuff, alluvium, tuff kristal yang mengeras, batuan gunungapi kuarter, kristal tuff, sedimen jura. Serta formasi penyusunnya terdiri dari Formasi Barisan, Formasi Lemau. 


\subsection{Tektonik Sumatera Barat}

Wilayah pantai barat Sumatera dan sekitarnya merupakan wilayah yang memiliki kerentanan bahaya gempabumi yang tinggi karena wilayah ini berada kurang lebih $250 \mathrm{~km}$ sebelah timur zona subduksi Sumatera yang bergerak sekitar 40 sampai dengan $70 \mathrm{~mm}$ per tahun. Daerah perbatasan lempeng ini merupakan zona seismisitas yang aktif, sehingga banyak terjadi gempa bumi tektonik yang diakibatkan oleh tumbukan antar lempeng tersebut. Proses tektonik yang terjadi di daerah Sumatera saat ini didominasi oleh terjadinya tumbukan antara lempeng Hindia dengan busur kepulauan Sumatera.

\subsection{Kegempaan Sumatera Barat}

Sepanjang pantai barat Sumatera, pantai selatan Jawa, selatan Bali merupakan bagian busur kepulauan daerah ini paling sering diguncang gempabumi. Gempabumi tersebut umumnya berkekuatan 4 - 6 SR, beberapa diantara berkekuatan lebih dari 6 SR. Berdasarkan sebaran, kekuatan dan kedalaman serta hubungan dengan kejadian, Pulau Sumatera terkenal dengan dua sumber gempabumi yaitu dari zona tumbukan antar lempeng (jalur penunjaman) dan jalur daratan, dimana yang sering terjadi yaitu pada jalur tunjaman.

\subsection{Sejarah Gempabumi Sumatera Barat}

Sejak tahun 1822, Provinsi Sumatera Barat sudah mengalami gempabumi. Hal ini terjadi karena Sumatera Barat berada dekat dengan lempeng aktif (Penunjaman Lempeng Samudera Hindia). Kota Padang setidaknya pernah mengalami setidaknya 19 kali gempabumi dengan besar guncangan $\mathrm{V}$ hingga IX skala MMI. Banyak juga bahaya lain yang terjadi setelah gempabumi, seperti bahaya longsoran, bahaya tsunami, bahaya likuifaksi, bahaya banjir. Gempabumi terparah terjadi di Padang panjang tahun 1926 dan Padang Pariaman 2009. Gempabumi Padang Pariaman tidak hanya berdampak untuk Indonesia, tetapi negara lain pun ikut merasakan getarannya.

\section{TEORI DASAR}

\subsection{Sumber Gempabumi}

Zona sumber gempa merupakan area yang mempunyai derajat gempa yang sama, dimana disetiap titik di zona tersebut memiliki kemungkinan yang sama akan terjadinya gempa dimasa mendatang. Sumber gempa dari zona fault atau sesar yang terdapat di lempeng tektonik dalam perkembangannya juga mengalami pergerakan dan juga akan memberikan kontribusi terhadap kejadian gempa. Terdapat 3 sumber gempa dalam Seismic Hazard Analysis yaitu sumber gempa patahan, sumber gempa subduksi dan sumber gempa background. Zona patahan (fault) yaitu zona kejadian gempa patahan dangkal (shallow crustal fault) dengan mekanisme strike-slip, reverse, atau normal yang terjadi pada patahan-patahan yang sudah terdefinisi dengan jelas, termasuk soal mekanisme slip-rate, dip, panjang patahan dan lokasinya. Sumber gempa patahan dangkal dimodelkan hingga kedalaman $15 \mathrm{~km}$. Sebagaimana dijelaskan dalam Gambar 1.

Zona subduksi (Megathrust) terjadi karena gerakan menunjam dari litosfer samudera terhadap litosfer daratan, hal ini terjadi karena kepadatan relatif litosfer samudera lebih besar dan karakter astenosfer yang relatif lemah. Rate dari subduksi dapat berupa recurrence rate Mmax untuk model karakteristik yang diambil dari data historis. Batas kedalaman maksimum dari sumber gempa ini dimodelkan hingga $50 \mathrm{~km}$ atau merupakan daerah Megathrust. Untuk daerah yang lebih dalam ( $>50 \mathrm{~km})$ atau daerah Benioff diwakili oleh model sumber gempa deep background dimana gempa-gempa yang terjadi merupakan gempa intraslab karena pada kedalaman tersebut kondisi batuan lebih ductile sehingga mekanisme gempa yang terjadi bukan merupakan akibat 
pertemuan antara dua permukaan bidang lempeng, seperti pada Gambar 2.

Zona background yaitu sumber gempa yang belum diketahui secara jelas. tetapi pada tempat tersebut didapati adanya beberapa kejadian gempa (kejadian gempa yang belum diketahui sesarnya).

\subsection{Pendekatan Geomorfologi}

Pendekatan geomorfologi didasarkan atas parameter geologi dan satuan morfologi seperti yang telah diperkenalkan oleh Matsuoka dkk. (2006). Pendekatan geomorfologi ditentukan oleh faktor kelerengan, elevasi, satuan batuan dan umur batuan. Klasifikasi kemiringan lereng dan dikombinasikan dengan elevasi harus dilakukan untuk menetapkan batasbatas pedataran, footslope, bukit dan gunung. Kombinasi antara faktor morfologi dan litologi akan menentukan satuan geomorfologi dan sumber material sedimen. Gunung dan bukit berumur tersier atau lebih tua ditetapkan sebagai sumber material sedimen. Gunung dan bukit berumur tersier adalah batuan yang berumur tua dan tahan terhadap pelapukan sehingga dijadikan dasar dalam perhitungan Vs30. Penetapan wilayah resiko dan bahaya gempabumi merupakan suatu yang realistis berarti mitigasi bencana gempabumi dengan menerapkan metode deduktif. Aspek geomorfologi merupakan faktor utama yang dapat digunakan untuk menentukan intensitas terjadinya gempabumi. Beberapa gempabumi merusak terjadi pada dataran alluvial dibandingkan perbukitan.

\subsection{Kecepatan Gelombang Geser (Vs30)}

$\mathrm{V}_{\text {s30 }}$ merupakan kecepatan gelombang geser hingga kedalaman $30 \mathrm{~m}$ dari permukaan. Nilai $V_{s 30}$ digunakan untuk menentukan klasifikasi batuan berdasarkan kekuatan getaran gempabumi akibat efek lokal serta digunakan untuk keperluan dalam perancangan bangunan tahan gempa. Berikut merupakan persamaan $\mathrm{V}_{\mathrm{s} 30}$ menurut Matsuoka 2006 dkk: $\log V s 30=a+b \log E v+$

$c \log S p+d \log D m \pm \sigma$

$V_{\text {s30 }} \quad=$ Rata-rata kecepatan gelombang geser $(\mathrm{m} / \mathrm{s})$

Ev = Elevasi $(\mathrm{m})$

Sp $\quad=$ Tangen dari slope $* 1000$

$D m=$ Jarak $(\mathrm{km})$ dari gunung atau bukit pra tersier atau tersier

Karakteristik atau sifat batuan sangat dibutuhkan untuk menganalisa sifat dinamis batuan, sehingga kekakuan batuan, dan kuat geser tanah dapat diketahui, dengan mengukur kecepatan gelombang geser hingga kedalaman $30 \mathrm{~m}$.

\subsection{Peak Ground Acceleration (PGA)}

Percepatan tanah maksimum atau Peak Ground Acceleration (PGA) adalah nilai percepatan tanah yang diukur selama gempa. PGA ini bisa dihitung dari besarnya magnitudo dan kedalaman gempa, kemudian dengan rumus atenuasi yang kini sudah berkembang hingga beberapa generasi.

Percepatan tanah maksimum dinyatakan dalam $g$ (Gravitational Acceleration $=\mathrm{g})$ atau $\mathrm{m} / \mathrm{s}^{2}(1 \mathrm{~g}=9,81$ $\mathrm{m} / \mathrm{s}^{2}$ atau dalam gal dimana 1 gal sama dengan $0,01 \mathrm{~m} / \mathrm{s}^{2} 1 \mathrm{~g}=981 \mathrm{Gal}$ ). Nilai percepatan tanah maksimum yang dihasilkan menunjukkan tingkat resiko bencana yang terjadi. Nilainya dapat digunakan sebagai bahan pertimbangan mitigasi bencana, desain struktur bangunan dan rencana tata ruang. Karena kondisi kompleks yang mempengaruhi PGA gempabumi berkekuatan sama dapat memberikan hasil yang berbeda dengan banyak gempabumi berkekuatan moderat menghasilkan nilai PGA signifikan lebih besar dari gempa berkekuatan besar.

\subsection{Fungsi Atenuasi}

Pemilihan fungsi atenuasi ini didasarkan pada kesamaan kondisi geologi dan tektonik dari wilayah dimana fungsi atenuasi itu dibuat. Fungsi atenuasi yang digunakan sebagian besar sudah menggunakan Next Generation 
Attenuation (NGA), dimana atenuasi ini dalam pembuatannya sudah menggunakan data gempa global (worldwide data). Dengan tidak tersedianya data untuk menurunkan suatu fungsi atenuasi di wilayah Indonesia, pemakaian fungsi atenuasi yang diturunkan dari wilayah lain tidak dapat dihindari.

Dalam analisis studi ini, rumus atenuasi yang digunakan untuk masingmasing model sumber gempa yaitu:

a. Sumber gempa Shallow Crustal (untuk model Patahan dan shallow background)

1) Boore-Atkinson NGA (2008)

2) Campbell-Bozorgnia NGA (2008)

3) Chiou-Young NGA (2008)

b. Sumber gempa subduksi interface (Megathrust) untuk model gempa subduksi

1) Geomatrix Subduction (Young et al, 1997)

2) Atkinson-Boore BC rock and global source subduction (Atkinson-Boore, 2003)

3) Zhao et al with variable $V_{s 30}$ (Zhao, 2006)

\subsection{Logic Tree}

Pendekatan dengan menggunakan logic tree memungkinkan untuk penggunaan beberapa alternatif metode atau model dengan menentukan faktor bobot yang menggambarkan persentase kemungkinan keakuratan relatif suatu model terhadap model lainnya. Pemakaian logic tree dalam Seismic Hazard Analysis (SHA) sangat diperlukan akibat adanya faktor ketidakpastian dalam pengelolaan data untuk analisis seismic hazard. Dengan adanya model treatment ini, data, parameter sumber gempa, dan model atenuasi yang digunakan bisa diakomodir dengan bobot sesuai dengan ketidakpastiannya. Model logic tree yang dipakai disesuaikan dengan model sumber gempa yang digunakan.

\subsection{Amplifikasi}

Amplifikasi merupakan perbesaran gelombang seismik yang terjadi akibat adanya perbedaan yang signifikan antar lapisan. Lapisan tanah yang lunak dapat menyebabkan getaran gempa yang lebih besar dibandingkan dengan lapisan tanah yang lebih keras pada waktu dilewati oleh gelombang gempa. Hal ini disebut dengan penguatan efek gelombang gempa. Nakamura (2000) menyatakan bahwa nilai faktor penguatan (amplifikasi) tanah berkaitan dengan perbandingan kontras impedansi lapisan permukaan dengan lapisan di bawahnya. Bila perbandingan kontras impedansi kedua lapisan tersebut tinggi maka nilai faktor penguatan juga tinggi, begitu pula sebaliknya.

\subsection{Deterministic Seismic Hazard Analysis (DSHA)}

Ada 2 metode yang digunakan dalam Seismic Hazard Analysis (SHA) yaitu DSHA (Deterministic Seismic Hazard Analysis) dan PSHA (Probabilistic Seismic Hazard Analysis. Metode DSHA umumnya diaplikasikan untuk mengestimasi percepatan gempa untuk konstruksi yang sangat membahayakan jika terjadi kerusakan, seperti bangunan Pembangkit Listrik Tenaga Nuklir (PLTN), bendungan besar, konstruksi yang dekat dengan sesar aktif, dan untuk keperluan emergency response. Deterministic Seismic Hazard Analysis (DSHA) banyak digunakan pada periode awal dari perhitungan seismic hazard. Konsep dasar DSHA adalah menentukan parameter ground motion dengan menggunakan magnitudo gempa maksimum dan jarak sumber gempa yang paling dekat dari titik pengamatan. DSHA diimplementasikan dengan menentukan skenario parameter gempa dengan cara memilih magnitudo maksimum dan lokasi terdekat dari sumber gempa yang diperkirakan akan menghasilkan dampak pada titik pengamatan. 


\section{METODOLOGI PENELITIAN}

\subsection{Data Penelitian}

Penelitian ini menggunakan data Koordinat Kota Padang. Data kegempaan dalam penelitian ini menggunakan parameter sumber gempa patahan (fault) dan sumber gempa subduksi (megathrust) di Wilayah Indonesia hasil Tim Teknik Revisi Gempabumi Indonesia. Untuk pendekatan geomorfologi, data yang digunakan yaitu peta SRTM dengan UTM $47 \mathrm{~S}$.

\subsection{Pengolahan Data}

\subsubsection{Penentuan Koordinat}

Penentuan koordinat ini dilakukan di Kota Padang dengan menggunakan software Google Earth. Setelah itu dilakukan perhitungan latitude dan longitude di beberapa titik Kota Padang. Dan didapatkan 270 titik koordinat.

\subsubsection{Pendekatan Geomorfologi}

Pendekatan geomorfologi ini dilakukan dengan penentuan kemiringan lokasi penelitian. Setelah data Slope (kemiringan) nya didapat dilakukan interpretasi geomorfologi daerah penelitian dengan mengidentifikasi geologi daerah penelitian. Setelah interpretasi geologi, maka dilakukan perhitungan nilai $\mathrm{V}_{\text {s30. }}$

\subsubsection{Perhitungan Vs30}

Estimasi Vs30 dihasilkan dari perhitungan empiris. Estimasi Vs30 dilakukan dengan menggunakan persamaan Matsuoka dkk. Hasil estimasi Vs30 selanjutnya digunakan untuk menentukan kelas tanah berdasarkan The NEHRP site classes.

\subsubsection{Deterministic Seismic Hazard Analysis (DSHA)}

Tahap-tahap yang dilakukan dalam penelitian ini dengan metode deterministik adalah sebagai berikut:

1. Melakukan identifikasi terhadap sumber-sumber gempa yang kemungkinan akan berpengaruh pada lokasi penelitian. Sumber-sumber gempa yang akan berpangaruh pada Kota Padang adalah sumber gempa sesar adalah Sesar Suliti karena memiliki nilai magitudo yang besar. Sementara untuk sumber gempa subduksi adalah Mid 2 Sumatera.

2. Menentukan parameter jarak terdekat dari sumber gempa dengan lokasi penelitian dan memilih magnitudo terbesar dari masing-masing sumber gempa yang telah diidentifikasi sebelumnya.

3. Menentukan parameter gerakan tanah pada lokasi pengamatan dengan menggunakan fungsi atenuasi. Dengan tidak tersedianya data untuk menurunkan suatu fungsi atenuasi di wilayah Indonesia, maka digunakan fungsi atenuasi yang diturunkan dari wilayah lain. Fungsi atenuasi yang digunakan Next Generation Attenuation (NGA), dimana atenuasi ini diturunkan menggunakan data gempa global (worldwide data). Dasar pemilihan fungsi atenuasi adalah berdasarkan sumber gempa, dimana secara umum dikategorikan dalam zona gempa subduksi. zona gempa background dan zona gempa shallow crustal (patahan). Dalam Seismic Hazard Analysis (SHA) sangat diperlukan pemakaian logic tree sangat diperlukan akibat adanya faktor ketidakpastian dalam pengelolaan data untuk analisis seismic hazard. Dengan adanya model treatment ini, data, parameter sumber gempa dan model atenuasi yang digunakan bisa diakomodir dengan bobot sesuai dengan ketidakpastiannya. Berdasarkan model logic tree, fungsi atenuasi yang digunakan untuk sumber gempa sesar adalah BooreAtkinson NGA, Campbell-Bozornia NGA, dan Chiou-Youngs NGA dengan bobot 1/3 untuk masing-masing persamaan. Sementara untuk sumber gempa subduksi adalah persamaan atenuasi Youngs, Atkinson-Boore, dan Zhao dengan masingmasing bobot 1/4 untuk persamaan atenuasi Youngs dan Boore-Atkinson sedangkan bobot untuk persamaan Zhao adalah $1 / 2$. 
4. Menentukan controlling earthquake berdasarkan hasil perhitungan terbesar yang diperoleh.

\section{HASIL DAN PEMBAHASAN}

\subsection{Analisis Site Class}

Nilai $V_{\text {s30 }}$ merupakan nilai yang menunjukkan kelas tanah. Nilai $\mathrm{V}_{\text {s30 }}$ tinggi menunjukkan jenis batuan yang keras. Semakin tinggi elevasi, nilai $\mathrm{V}_{\mathrm{s} 30}$ semakin besar. Daerah yang memiliki nilai $\mathrm{V}_{\mathrm{s} 30}$ tinggi, menunjukkan suatu daerah tersebut berada diatas batuan keras, sedangkan daerah yang memiliki nilai $\mathrm{V}_{\text {s30 }}$ kecil menunjukkan bahwa suatu daerah tersebut berada diatas batuan lunak. Nilai $V_{\text {s30 Kota }}$ Padang menunjukkan bahwa Kota Padang berada pada kelas tanah $\mathrm{A}$, kelas tanah $\mathrm{B}$, kelas C, kelas tanah D. Hal ini ditunjukkan pada Gambar 3. Daerah yang berada pada kelas tanah A diantaranya adalah Kecamatan Kecamatan Lubuk Kilangan dan Kecamatan Pauh. Tipe kelas tanah A merupakan tipe kelas dengan batuan sangat keras. Tipe kelas $C$ merupakan tipe kelas dengan jenis tanah sangat padat dan lunak daerah yang berada pada kelas C adalah beberapa daerah di Kecamatan Nanggalo, Kcamatan Koto Tengah, Kecamatan Padang Barat, daerah ini juga sebagian berada pada kelas tanah D. Sedangkan tipe kelas tanah D merupakan tipe kelas dengan jenis tanah kaku (antara lunak dan keras).

\subsection{Analisis Bahaya Gempabumi Deterministik}

Untuk sumber gempa yang digunakan dalam perhitungan ini adalah sumber gempa patahan (Patahan Suliti) dan sumber gempa subduksi (Mid 2 Sumatera). Dari masing-masing sumber gempa memiliki nilai magnitudo 7,4 Mw dan 8,5 Mw. Perhitungan percepatan tanah maksimum pada batuan dasar dilakukan dengan menganggap semua batuan homogen sehingga memperihatkan bahwa percepatan hanya dipengaruhi oleh parameter sumber gempabumi (jarak dan magnitudo) saja. Gambar 4 menunjukkan peta persebaran PGA Rock untuk sumber gempa patahan. Dari peta persebaran PGA Rock sumber gempa patahan dapat dilihat bahwa daerah yang dekat dengan rupture area memiliki nilai PGA yang lebih besar dibandingkan daerah yang jauh dengan rupture area. Gambar 5 menunjukkan distribusi nilai PGA pada batuan dasar untuk sumber gempa subduksi. Pada Gambar 5 dapat dilihat bahwa disebelah baratdaya Kota Padang, nilai PGA pada batuan dasar memiliki nilai yang lebih besar. Semakin ke arah Timur nilai PGA semakin kecil, hal ini dipengaruhi oleh jarak dari sumber gempa dengan daerah penelitian tersebut yang semakin jauh.

Perhitungan PGA juga dilakukan pada permukaan, hal ini dilakukan karena untuk melihat perbandingan nilai maksimum pada batuan dasar dan pada permukaan. Perbandingan ini dilakukan dengan menggunakan nilai $\mathrm{V}_{\text {s30 }}$ untuk nilai percepatan maksimum pada permukaan. Hal ini juga menghasilkan nilai site class. Untuk nilai $\mathrm{V}_{\mathrm{s} 30}$ pada batuan dasar, nilai $\mathrm{V}_{\text {s30 }}$ dianggap homogen yakni 1500 . Sedangkan nilai $V_{\text {s30 }}$ untuk permukaan didapatkan dari pendekatan geomorfologi daerah penelitian dengan mempertimbangkan morfologi daerah sekitar sehingga menghasilkan nilai $\mathrm{V}_{\mathrm{s} 30}$ yang berbeda-beda. Gambar 6 merupakan peta persebaran PGA soil untuk sumber gempa patahan (Suliti).

Nilai PGA tertinggi mencapai 0,0573 g. Daerah yang termasuk dalam zona sangat rawan terhadap guncangan jika dilihat dari peta persebaran PGA Soil patahan ini diantarannya adalah Kecamatan Koto Tengah, Kecamatan Padang Utara, Kecamatan Nanggalo dan beberapa daerah di Kecamatan Kuranji. Gambar 7 menunjukkan distribusi PGA soil pada sumber gempa subduksi (Mid 2 Sumatera). Pada Gambar $\mathbf{7}$ dapat diketahui bahwa Kecamatan Padang Barat, Kecamatan Padang Utara berada pada zona sangat rawan dengan besar 
guncangan 0,0685 g sampai dengan 0,0766 g, dari Gambar 7 juga dapat dilihat bahwa daerah yang aman terhadap guncangan adalah Kecamatan Nanggalo, Kecamatan Kuranji dan Koto Tengah termasuk dalam zona rawan terhadap guncangan, nilai PGA mencapai 0,0644 g hingga 0,0685 g. Berdasarkan besar kecilnya nilai PGA permukaan yang diperoleh dari hasil analisa bahaya gempa deterministik dapat memberikan gambaran tentang kemampuan lapisan tanah dalam menahan guncangan maksimum akibat getaran gempa. Semakin besar nilai PGA yang pernah terjadi disuatu tempat, maka semakin besar bahaya dan resiko gempabumi yang mungkin terjadi.

\subsection{Analisis Amplifikasi}

Pada saat terjadi peristiwa gempa, lapisan tanah di atas batuan dasar (bedrock) dapat berperilaku sebagai filter yang dapat memperbesar gerakan tanah dan amplitudo dari guncangan tanah. Gambar 8 merupakan peta amplifikasi dari sumber gempa patahan. Untuk sumber gempa patahan, daerah yang memiliki amplifikasi sangat tinggi adalah sebagian Kecamatan Padang Barat, Sebagian Kecamatan Padang Utara, sebagian Kecamatan Nanggalo.peta amplifikasi dari sumber gempa patahan. Pada peta amplifikasi Gambar 9 menunjukkan nilai amplifikasi pada sumber gempa subduksi terhadap Kota Padang. Zona warna merah menunjukkan nilai amplifikasi sangat tinggi 2,0607 (> 9 kali), daerah yang memiliki zona amplifikasi sangat tinggi, maka kerawanan bahaya dari guncangan gempa ini sangat tinggi, daerah yang berada pada zona amplifikasi sangat tinggi adalah sebagian Kecamatan Nanggalo, sebagian Kecamatan Padang Barat, sebagian Kecamatan Kuranji dan sebagian keil Kecamatan Koto Tengah.

\subsection{Analisis Tingkat Bahaya Gempabumi}

Analisis dari peta ini dapat dilakukan dengan cara menggabungkan data dari nilai Vs30, nilai PGA Rock, nilai PGA Soil serta nilai amplifikasi baik dari sumber gempa patahan maupun sumber gempa subduksi. Hal ini dilakukan unuk memudahkan intrepretasi daerah yang memiliki tingkat kerawanan tinggi jika terjadi gempa. Gambar 10 peta kompilasi (gabungan) dari nilai $\mathrm{V}_{\mathrm{s} 30}$, nilai PGA rock, PGA soil dan amplifikasi sumber gempa patahan. Penggabungan peta ini bertujuan untuk memudahkan dalam analisis tingkat bahaya gempa dari sumber gempa patahan. Dari analisis peta ini menunjukkan bahwa Kecamatan Koto Tengah, sebagian Kecamatan Kuranji, sebagian Kecamatan Nanggalo, beberapa daerah di Kecamatan Padang Utara dan sebagian dari Kecamatan Padang Barat merupakan zona sangat tinggi jika terjadi gempa dari sumber patahan (Suliti). Gambar 11 merupakan peta kompilasi dari sumber gempa subduksi (Mid 2 Sumatera). Dari peta ini, dapat diketahui bahwa Kecamatan Padang Barat, Kecamatan Padang Utara, sebagian dari Kecamatan Nanggalo termasuk dalam zona sangat rawan akan gempabumi

\section{KESIMPULAN DAN SARAN}

\subsection{Kesimpulan}

Kesimpulan dari penelitian ini adalah sebagai berikut:

1. Nilai $V_{s 30}$ untuk Kota Padang berkisar antara 226,4644 m/s berada pada kelas tanah E (Batuan Lunak) hingga 4469,041 m/s yang berada pada kelas tanah A (Batuan Keras).

2. Nilai percepatan tanah maksimum (PGA) sumber gempa Subduksi di batuan dasar berkisar antara 0,0374 g. Sementara percepatan tanah maksimum (PGA) di permukaan berkisar antara 0,0769 g. Sedangkan untuk nilai PGA pada sumber gempa patahan (Patahan Suliti) di batuan dasar berkisar antara 0,0376 g, sementara nilai PGA di permukaan berkisar 0,0573 g. 
3. Daerah yang memiliki dampak parah jika terjadi gempa yang bersumber dari patahan adalah Kecamatan Koto Tengah, Kcamatan Padang Barat, Kecamatan Padang Utara dengan nilai amplifikasi tertinggi yakni berada pada nilai 1,7690 (> 9 kali) yang menunjukkan bahwa perbesaran gelombang didaerah tersebut tinggi. Sedangkan jika terjadi gempa dengan sumber gempa subduksi daerah yang sangan rawan adalah Kecamatan Padang Barat, Kecamatan Koto Tengah, Kecamatan Padang Utara dengan nilai amplifikasi 2,0607 (> 9 kali). Dan daerah tersebut berada pada kelas tanah D.

\subsection{Saran}

Untuk pengembangan penelitian analisis seismic hazard selanjutnya perlu dilakukan pemodelan untuk membuat satuan geomorfologi yang cocok untuk Indonesia berdasarkan ketersediaan data geologi dan morfologi Indonesia. Selain itu juga perlu dilakukan penelitian lebih lanjut mengenai fungsi atenuasi dan persamaan geomorfologi untuk daerah Indonesia, karena Indonesia sendiri merupakan negara yang memiliki tektonik yang komplek. Sehingga hasil penelitian benar-benar akurat untuk Indonesia.

\section{UCAPAN TERIMA KASIH}

Penulis mengucapkan terima kasih kepada Amalfi Omang sebagai pembimbing lapangan, serta Syamsurijal S.Si., M.Si dan Dr. Nandi Khaerudin S.Si., M.Si yang telah membimbing dan memberikan dukungan terhadap penyelesaian penelitian ini.

\section{DAFTAR PUSTAKA}

Athanasius, C. dan Solikhin, A., 2015. Pendugaan Kecepatan Gelombang
Permukaan (VS30) di Pulau Sulawesi Berdasarkan Klasifikasi Geomorfologi dan Aplikasinya. Laporan Penelitian Pusat Vulkanologi dan Mitigasi Bencana Geologi. Bandung

Atkinson, G.M. dan Boore, D.M., 2003. Empirical Ground-Motion Relations for Subduction-Zone Earthquakes and Their Application to Cascadia and Other Regions. Bulletin of the Seismological Society of America. Volume 93, nomor 4, pp. 17031729.

Boore, D.M. dan Atkinson, G.M., 2008. Ground-motion prediction equations for the average horizontal component of PGA, PGV, and 5\%damped PSA at spectral periods between $0.01 \mathrm{~s}$ and $10.0 \mathrm{~s}$. Earthquake Spectra. Volume 24, nomor 1.

Campbell, K. dan Bozorgnia, Y., 2008. Ground motion model for the geometric mean horizontal component of PGA, PGV, PGD and $5 \%$ damped linear elastic response spectra for periods ranging from 0.01 to 10.0 s. Earthquake Spectra. Volume 24, nomor 1.

Chiou, B. dan Youngs, R.R., 2008. A NGA model for the average horizontal component of peak ground motion and response spectra. Earthquake Spectra. Volume 24, nomor 1.

Irsyam, M.D., Sengara, W., Aldiamar, F., Widiyantoro, S., Triyoso, W., Natawidjaja, D.H., Kertapati, E., Meilano, I., Suhardjono., Asrurifak, M. dan Ridwan, M., 2010. Ringkasan Hasil Studi Tim Revisi Peta Gempabumi Indonsia 2010. Kementrian Pekerjaan Umum. 
Matsuoka, M., Wakamatsu, K., Fujimoto, K. dan Midorikawa, S., 2006. Average Shear-Wave Velocity Mapping Using Japan Engineering Geomorphologic Classification Map.Structural Eng./Earthquake Eng., JSCE, Vol.23, No.1, 57s-68s, 2006 April. (Translated from a paper which originally appeared on
Journal of Structural Mechanics and Earthquake Engineering, JSCE, No.794/I-72, pp.239-251, 2005 July).

Tim Revisi Peta Gempa Indonesia., 2010. Ringkasan Hasil Studi Tim Revisi Peta Gempa Indonesia.

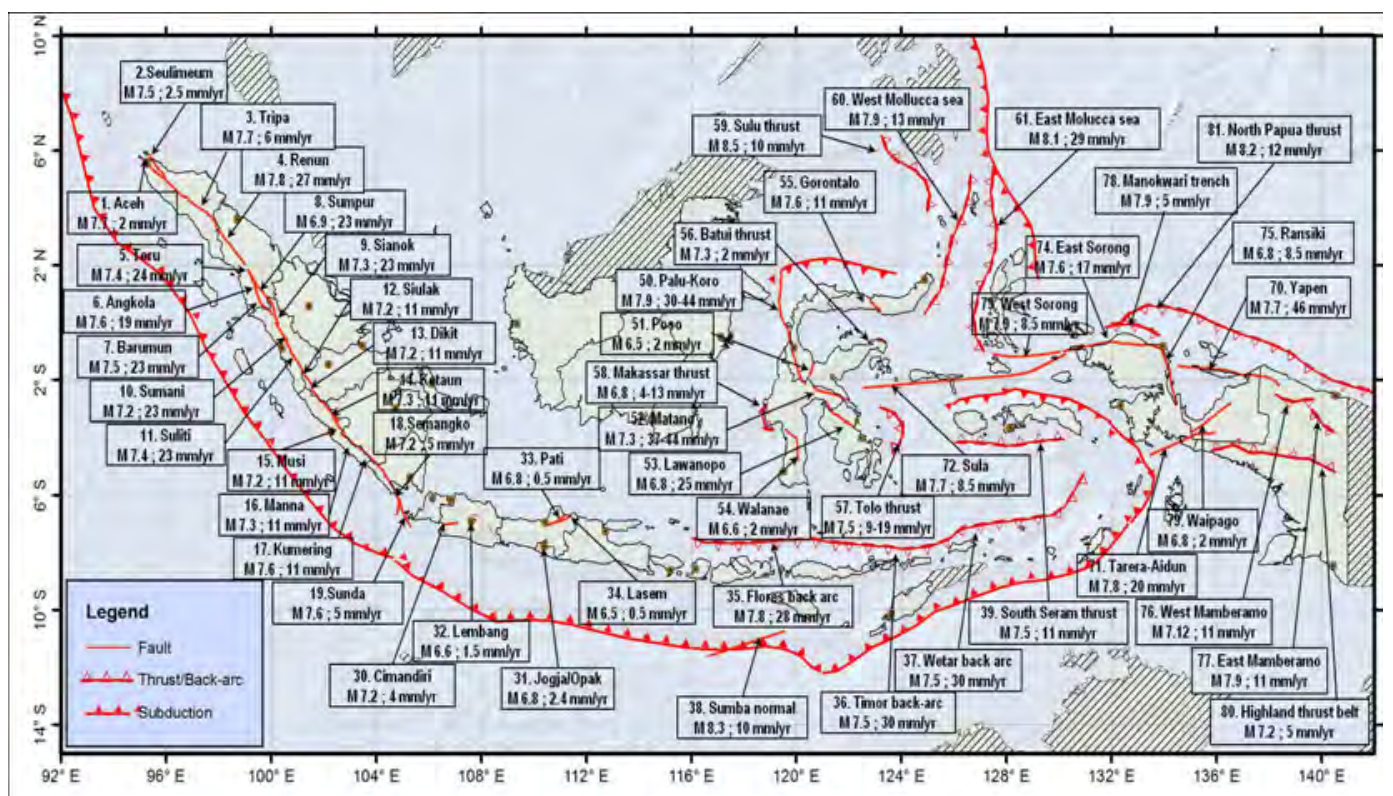

Gambar 1. Peta sumber gempabumi patahan (fault) (Tim Revisi Peta Gempabumi Indonesia, 2010).

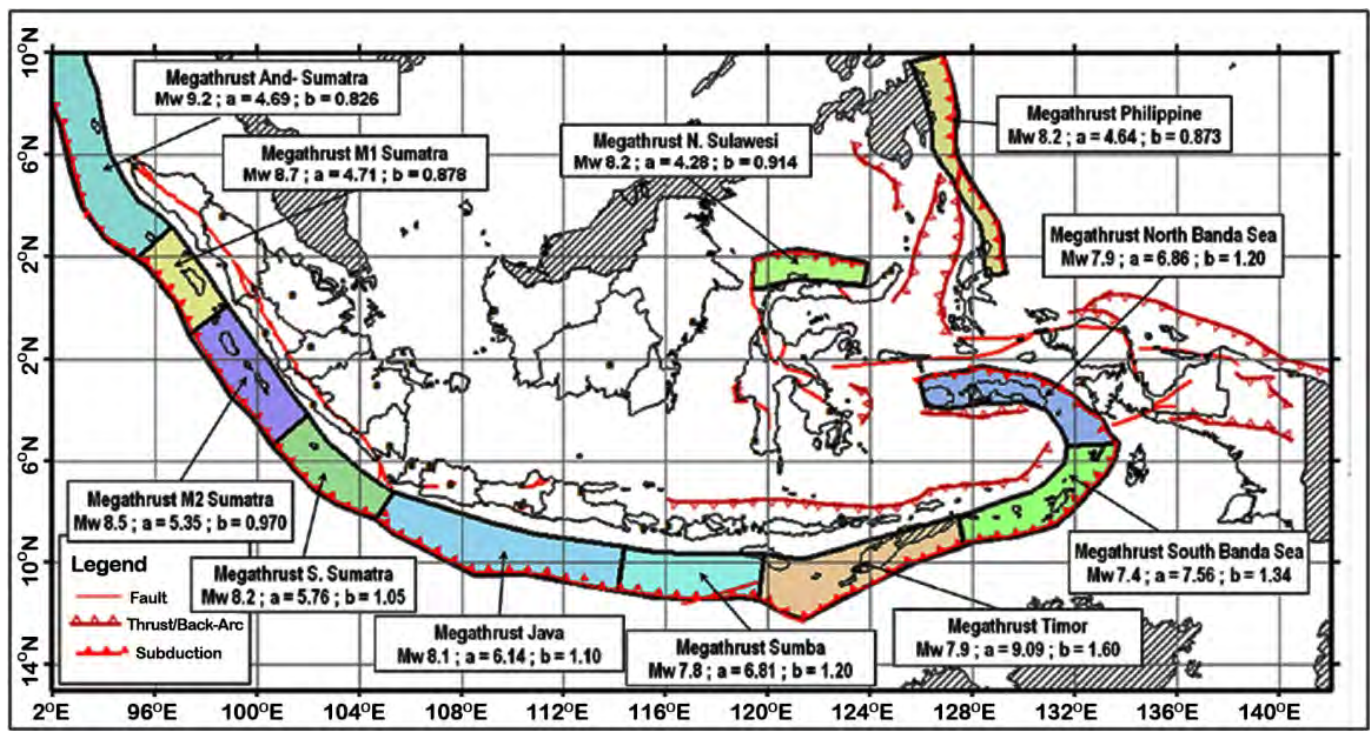

Gambar 2. Sumber gempabumi subduksi (Megathrust) (Tim Revisi Gempabumi, 2010). 


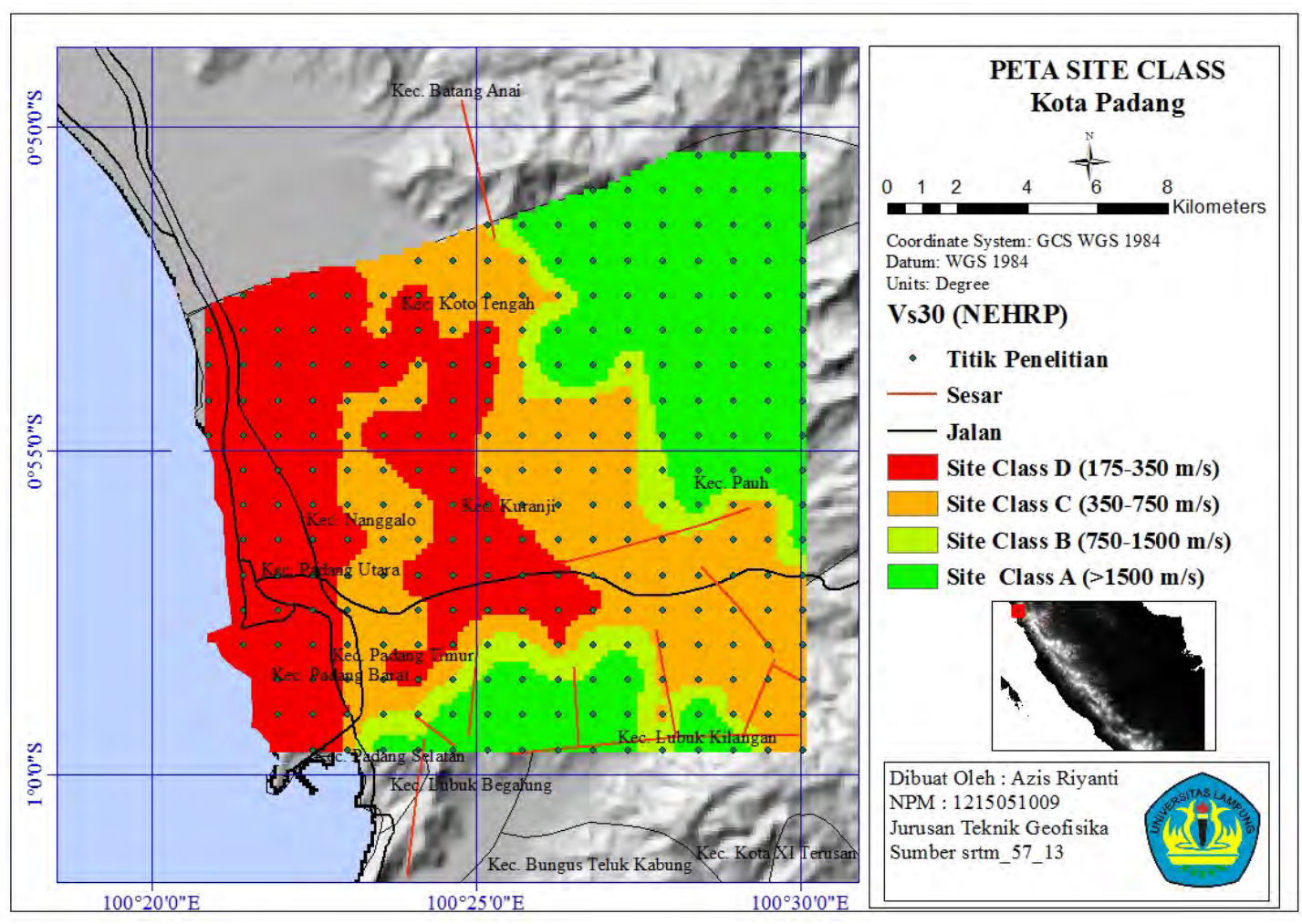

Gambar 3. Peta Site Class Kota Padang

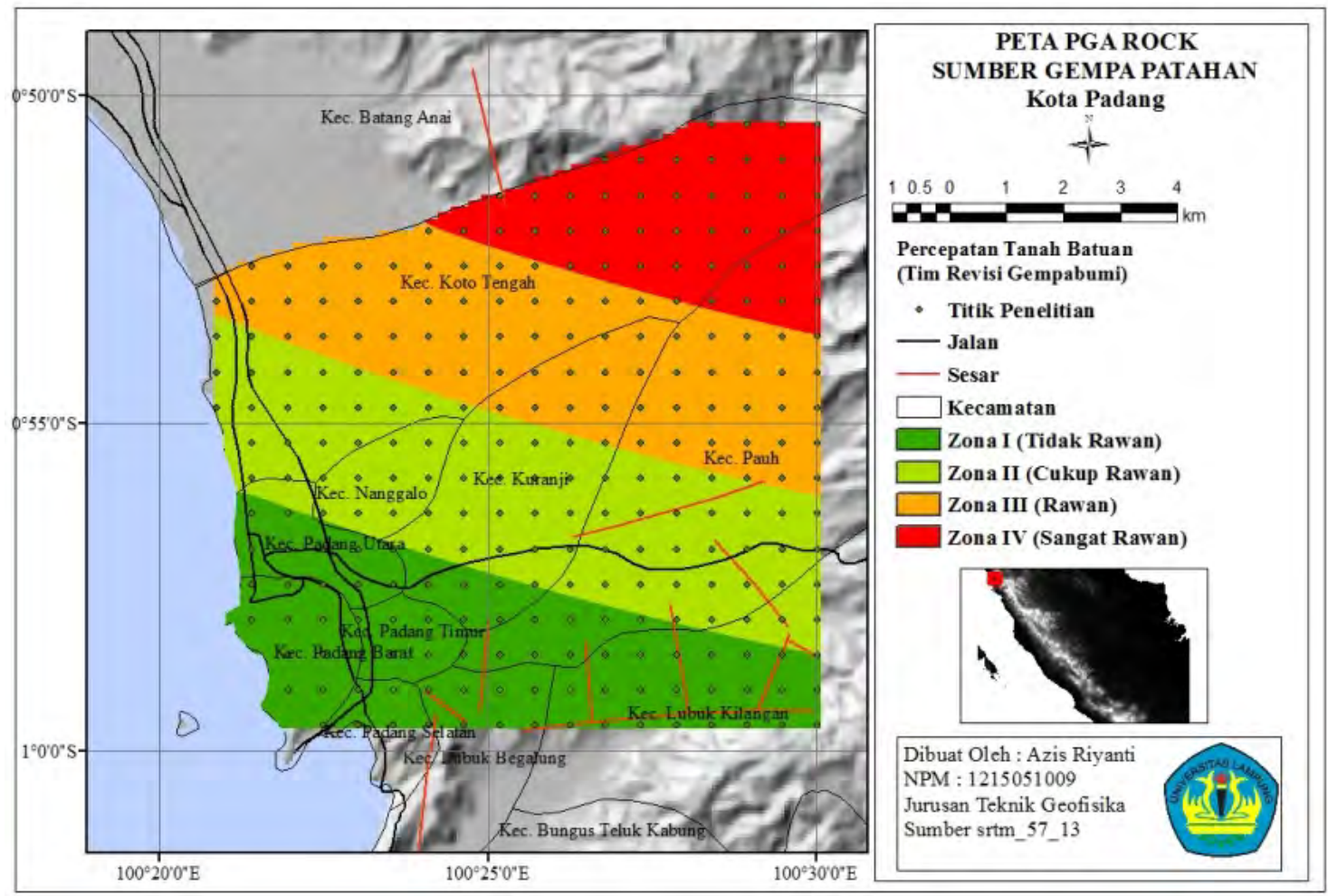

Gambar 4. Peta PGA Rock Sumber gempa patahan Kota Padang 


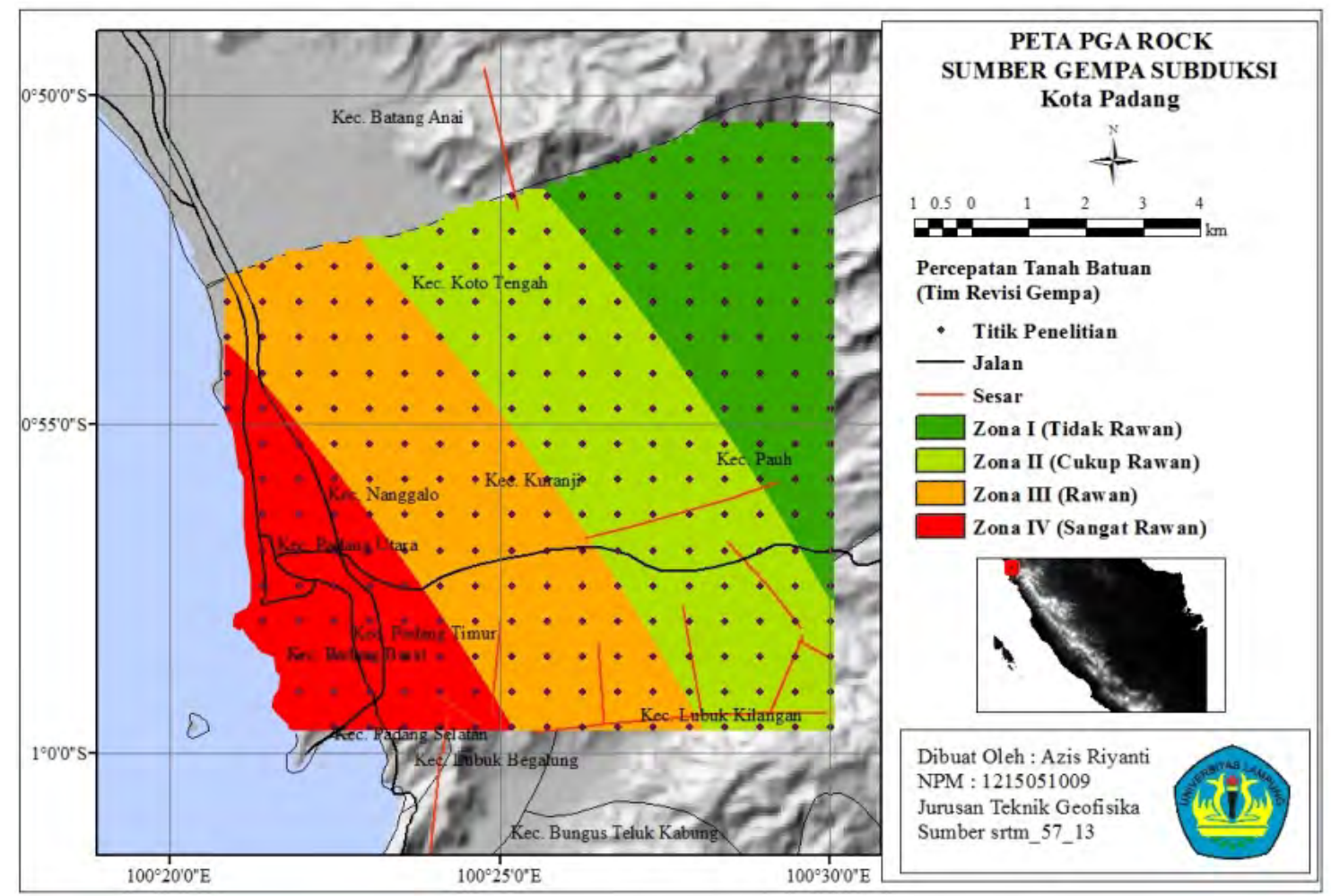

Gambar 5. Peta PGA Rock Sumber gema subduksi Kota Padang

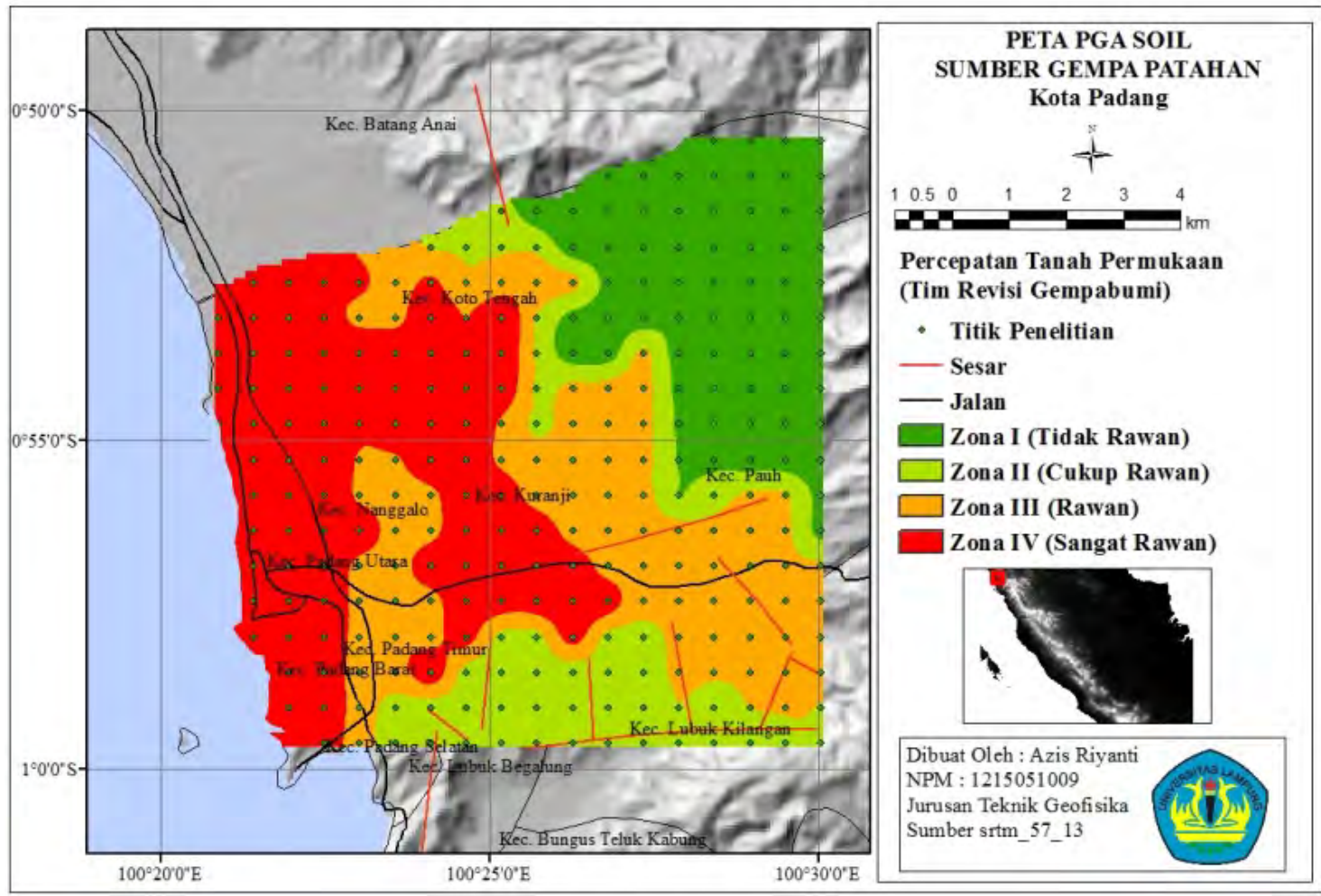

Gambar 6. Peta PGA Soil Sumber gempa patahan 


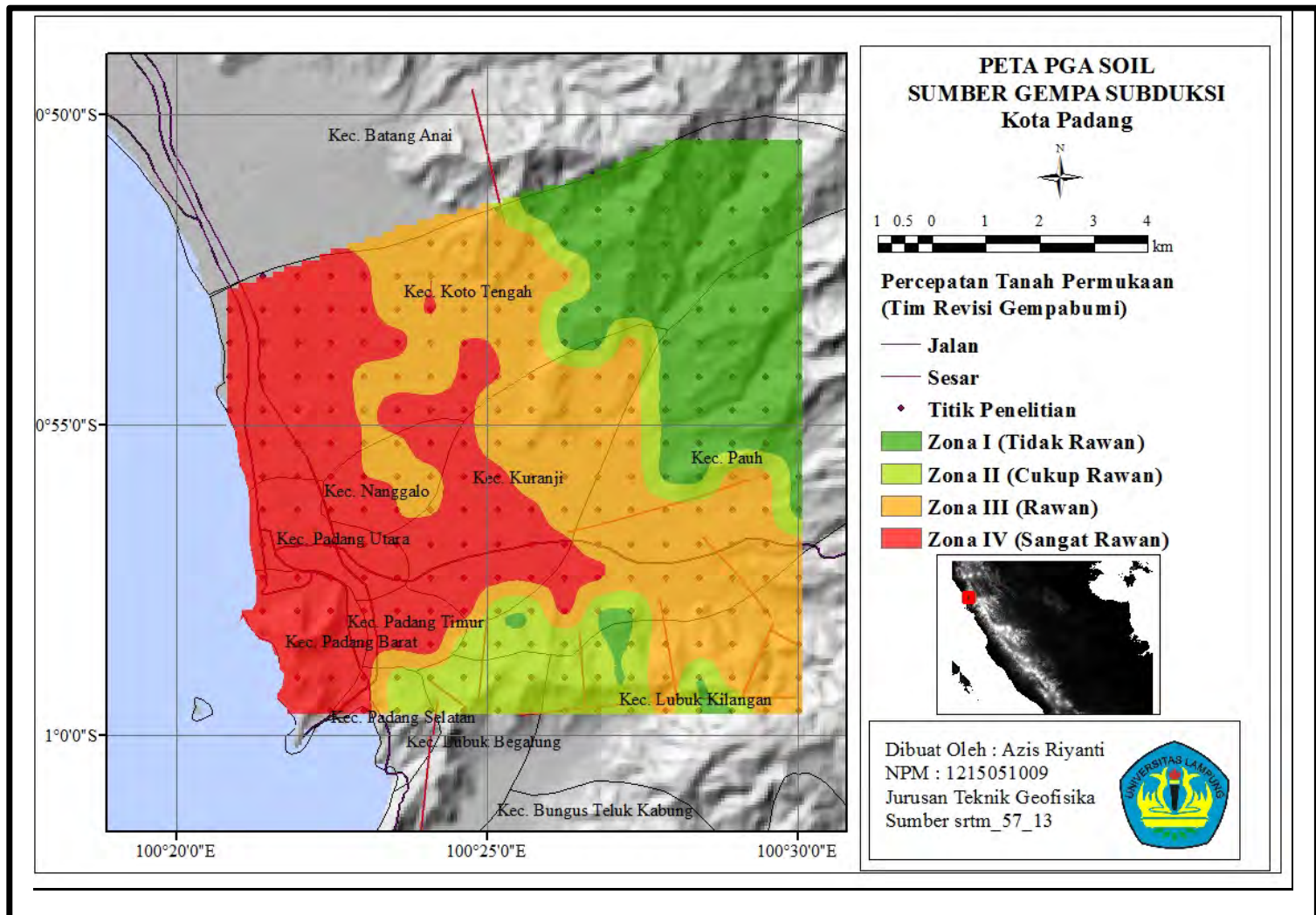

Gambar 7. Peta PGA Soil Sumber gempa subduksi

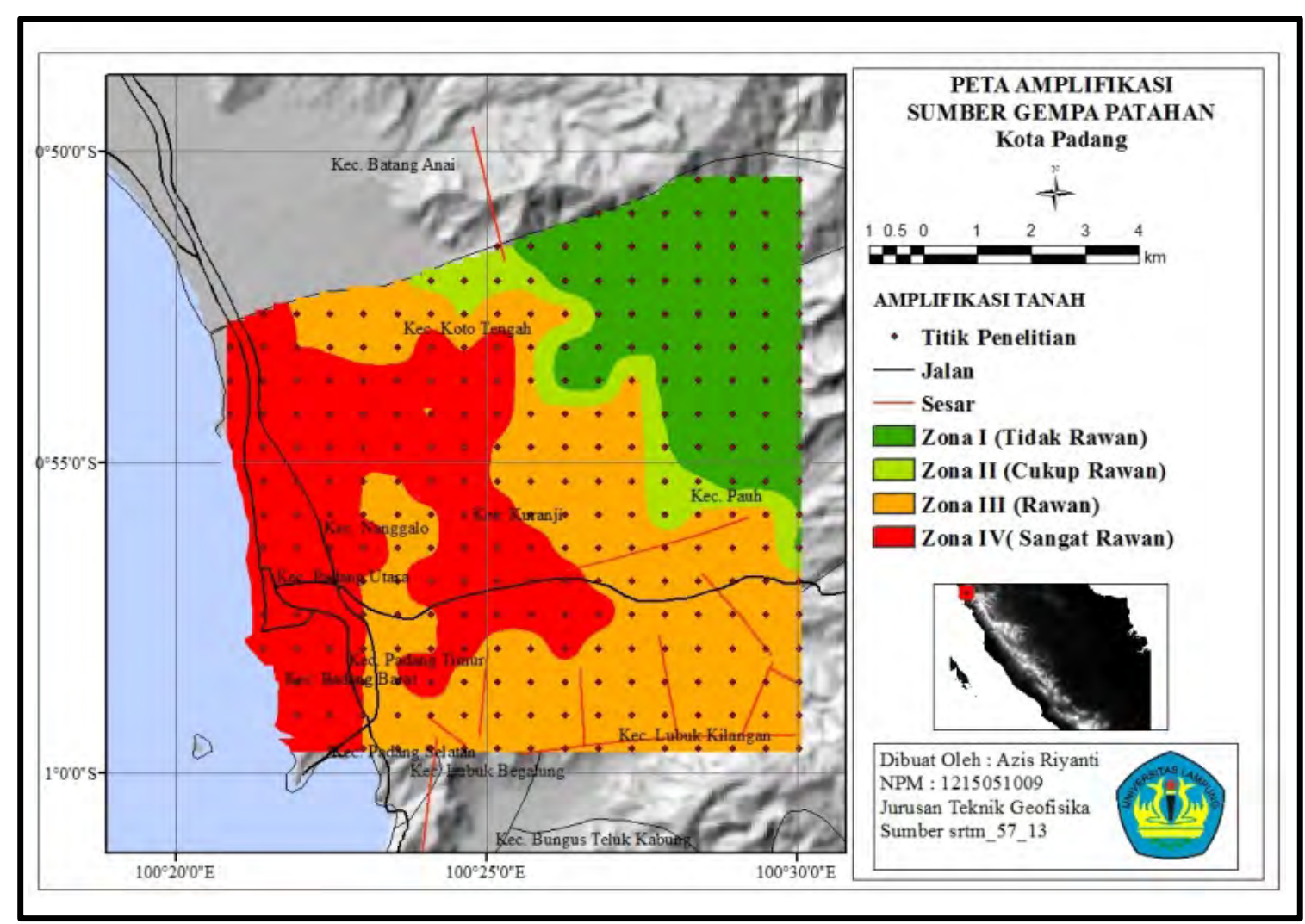

Gambar 8. Peta Amplifikasi sumbr gempa patahan 


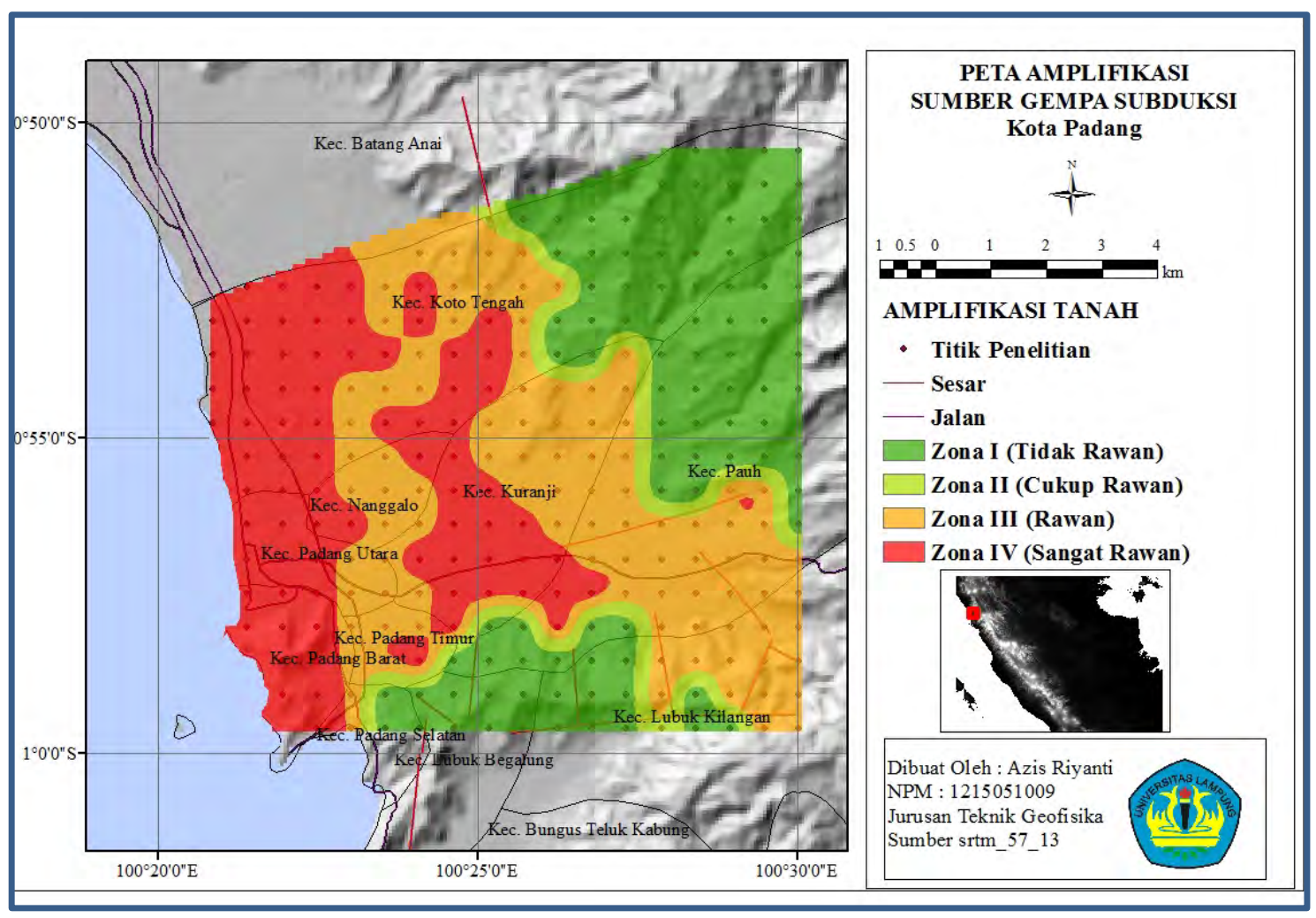

Gambar 9. Peta Amplifikasi sumber gempa subduksi Kota Padang

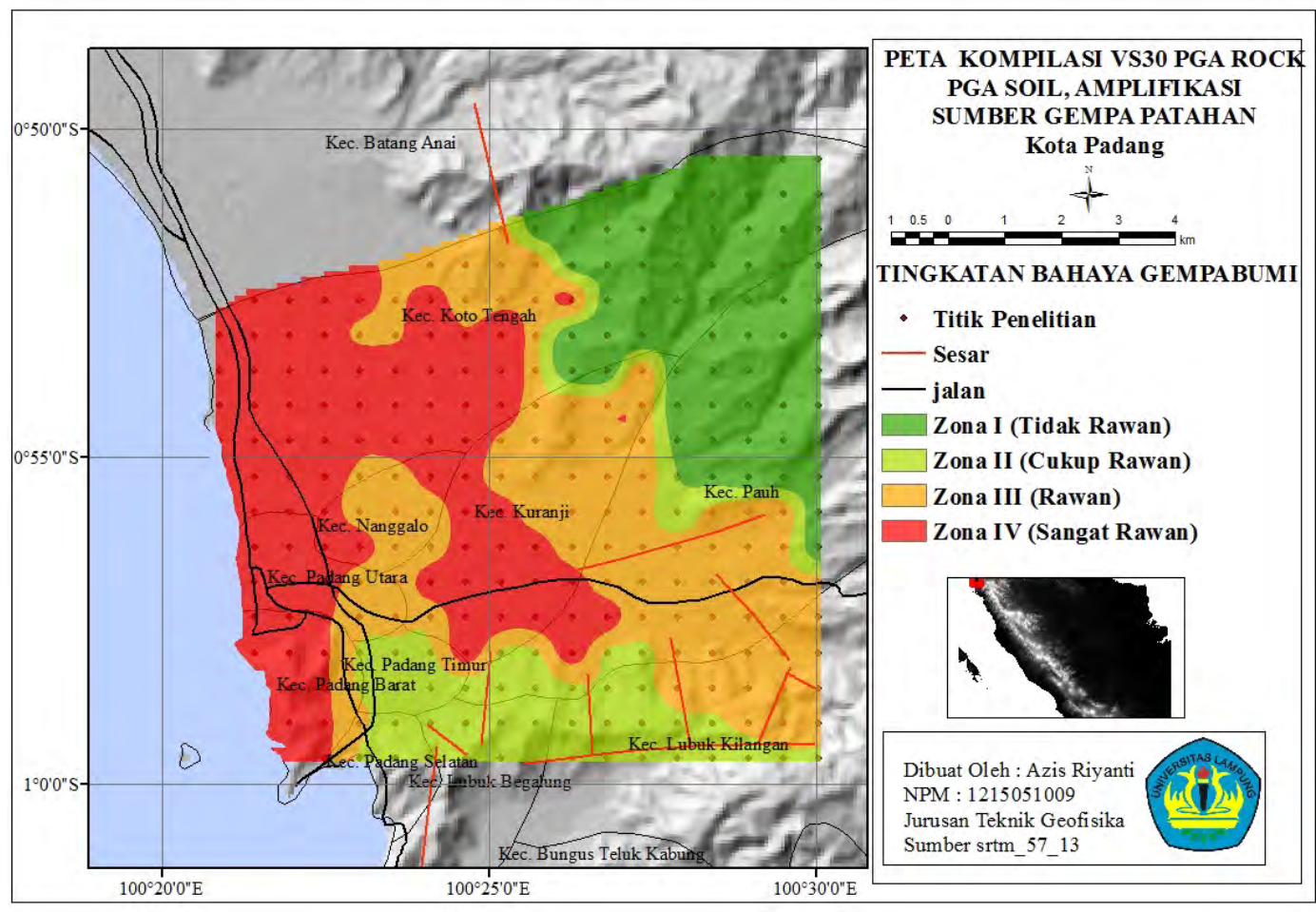

Gambar 10. Peta Kompilasi Vs30, PGA Rock, PGA Soil dan Amplifikasi sumber gempa patahan 


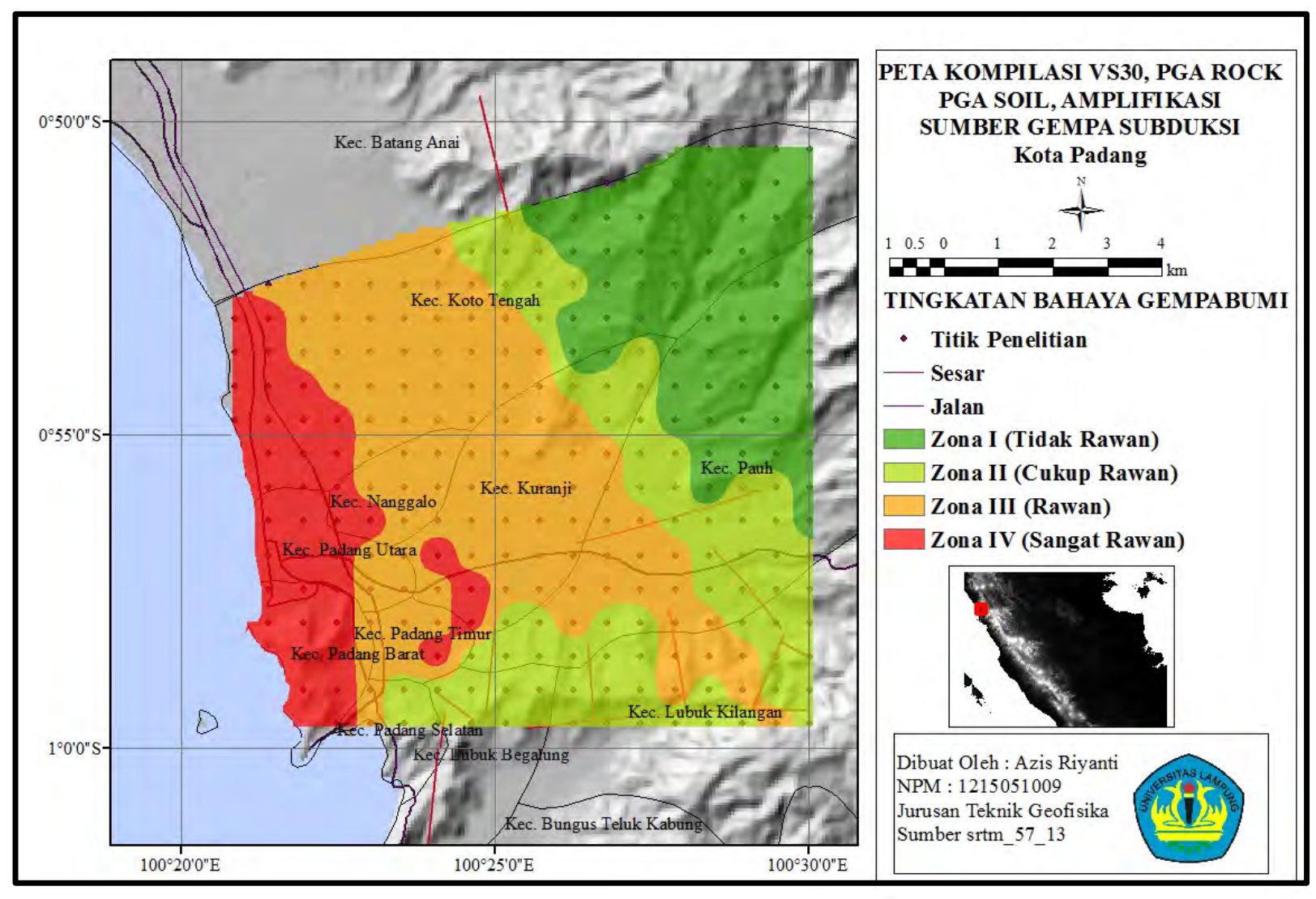

Gambar 11. Peta Kompilasi Vs30, PGA Rock, PGA Soil dan Amplifikasi Sumber gempa subduksi 